\title{
Antiproliferative Activity of Selected Triterpene Acids from Rosemary on Metastatic Melanoma Cell Line WM-266-4
}

\author{
Suzana Isaković-Vidović ${ }^{1,2}$, Barbara Dariš ${ }^{3}$ D, Željko Knez $^{2}$, Kristina Vidović $^{4}$, Dejan Oprić $^{5}$, Polonca Ferk ${ }^{6 *}$ (iD \\ ${ }^{1}$ Department of Radiology, Izola General Hospital, Izola, Slovenia; ${ }^{2}$ Faculty of Chemistry and Chemical Engineering, University \\ of Maribor, Maribor, Slovenia; ${ }^{3}$ Department of Pharmacology and Toxicology, Faculty of Medicine, Institute of Biomedical \\ Sciences, University of Maribor, Maribor, Slovenia; ${ }^{4}$ Faculty of Medicine, University of Belgrade, Belgrade, Serbia; ${ }^{5}$ Faculty of \\ Medicine, Institute of Pathology, University of Belgrade, Belgrade, Serbia; ${ }^{6}$ Institute of Biostatistics and Medical Informatics, \\ Faculty of Medicine, University of Ljubljana, Ljubljana, Slovenia
}

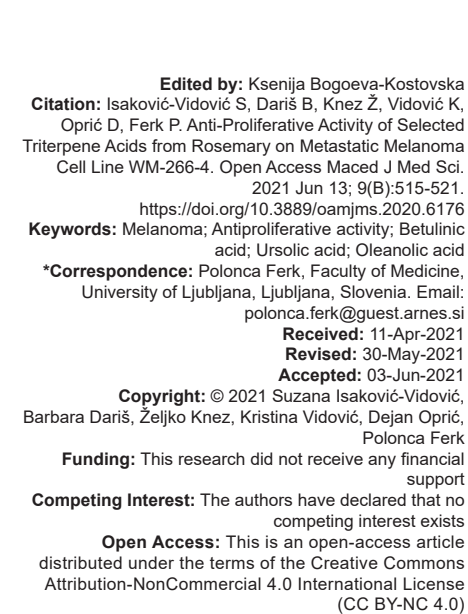

\section{Introduction}

Malignant melanoma is skin cancer that has evolved to become a common malignancy and a major public health problem [1]. It originates from melanocytes, which are present in all areas of epidermis and in the parts of the eye and upper respiratory, gastrointestinal, and genitourinary tracts [2]. The incidence of melanoma has been steadily increasing during the past few decades in most fair-skinned populations and it is the fifth leading cancer in males and the seventh in females in the United States [3]. Increasing incidence rates have been observed also in Europe, with south/north and east/west variations [1]. Melanoma incidence has been more profoundly raised in North Europe, particularly in Scandinavian countries. Increases in incidence rates are not followed by a similar trend in mortality rates [4]. Mortality has decreased during the past few decades because of heightened awareness and screening programs resulting in

\begin{abstract}
BACKGROUND: Natural products and their derivatives, particularly secondary metabolites, have been recognized wide rangid (BA), oleanolic acid (OA), and ursolic acid (UA) are highly valuable triterpenic acids because of their

AIM: Therefore, the aim of our study

METHODS: BA, UA, and OA have been prepared in dimethyl sulfoxide in concentration range from 0.002 to $200 \mu \mathrm{M}$ to measure proliferation activity of the metastatic melanoma cell line WM-266-4 after being exposed to selected

RESULTS: Our results showed decreased cell proliferation activity after $4 \mathrm{~h}$ of incubation of WM-266-4 cells with and UA+OA. The highest inhibitory effect was noted when cells were incubated with selected triterpenic acids and both combinations of UA+OA during the incubation period of $48 \mathrm{~h}$. When compared to control cells CONCLUSION: Our encouraging results could be a good starting point for further studies on possible use of BA, UA and $\mathrm{OA}$ in prevention and treatment of metastatic melanoma.
\end{abstract}

earlier detection. However, the treatment of melanoma remains difficult. Many of the chemotherapeutic agents used show a limited selectivity for tumor cells and cause adverse effects [5]. Furthermore, besides known adverse effects, resistance to chemotherapy is frequently observed in melanoma. Understanding skin cancer incidence is important for planning prevention and treatment strategies. It has been shown that many clinically approved anticancer drugs were of natural origin, that is, natural products, derivatives, or synthesized molecules based on natural product compound pharmacophores [6]. Moreover, well-known anti-cancer drugs include Catharanthus alkaloids, colchicine, etoposide, and Taxol [7]. In Europe, several of the traditionally used medicines have been developed into modern registered drugs, which have been studied in clinical trials [6], [7]. Furthermore, many of modern drugs have been developed from purified compounds, isolated from medicinal herbs and/or plants, based on their traditional pharmacological use [7]. There are more than 100,000 known secondary metabolites, 
and for many of them, their bioactive properties and mechanisms of action are yet unknown [6]. Plant secondary metabolites such as polyphenol compounds, alkaloids, and terpenes possess diverse pharmacological properties, including cytotoxic and cancer chemopreventive effects [8], [9], [10]. The latter may act during different phases of the malignant tumor development and involve various mechanisms [1], [4]. During the past two decades, a growing number of studies which investigated the effects of polyphenols on different cancer cell lines have been observed. Many of them analyzed the antiproliferative and antimetastatic capacity of such compounds against melanoma cell lines [11], [12], [13]. In addition, triterpenoid-derived compounds (including triterpenic acids) isolated from different medicinal plants have been shown to possess significant antiproliferative activity against cancer cell lines with promising selectivity for malignant cells [5], [7], [14], [15].

Rosemary (Rosmarinus officinalis L.) is a medicinal plant that belongs to the Lamiaceae family, native of Mediterranean regions. The phytochemicals present in $R$. officinalis are rosmarinic acid, camphor, caffeic acid, ursolic acid (UA), betulinic acid (BA), carnosic acid, and carnosol [6], [15]. BA, UA, and oleanolic acid (OA) belong to the group of pentacyclic triterpenes [11], [13]. While BA and UA have been a subject of many research studies, OA has been studied to a lesser extent on cell cultures [11]. Previous results indicate that $B A, U A$, and $O A$ have pleiotropic biologic activities such as antiinflammatory, cytotoxic, and antiproliferative activities on cancer cells [8], [16]. BA and its derivatives have been extensively researched for their strong cytotoxic properties against melanoma [16], [17]. Recently, OA has attracted more attention due to its marked antitumor effects and pharmacological safety [18]. Furthermore, UA and OA were found as effective antihepatoma agents with marked anti-cancer activity. They also show protective effects against $\mathrm{H}_{2} \mathrm{O}_{2}$ induced DNA damage in leukemic L1210, K562, and HL-60 cells as well as significant antioxidant effects [18], [19], [20], [21], [22], [23]. In addition, three pentacyclic triterpenoids, 12-oleanen-27-oic acid derivatives, 3 $\beta$-hydroxy-12-oleanen-27-oic acid (ATA), $3 \beta$, 6 $\beta$-dihydroxy-12-oleanen-27-oic acid (ATB), and $3 \beta$-acetyl-12-oleanen-27-oic acid (ATC), isolated from the rhizomes of Astilbe chinensis (Maxim.) Franch. et Savat. (Saxifragaceae), have shown a strong cytotoxic activity toward human ovarian carcinoma HO-8910 cells, human cervical squamous carcinoma HeLa cells, and human leukemic HL60 cells [24].

According to the previous studies, the aim of our research was to investigate the possible antiproliferative effect of triterpenes $B A, U A, O A$, and combined effect of mixture of UA+OA (1:1 and 3.5:1) on cell proliferation in selected metastatic melanoma cell line.

\section{Methods}

\section{Cell culture}

Skin metastatic melanoma cell line WM-266-4 American Type Culture Collection (ATCC ${ }^{\circledR}$ CRL1676 ${ }^{\mathrm{TM}}$ ) was purchased from (ATCC, Manassas, VA, USA). The cell line was isolated from lymph node metastasis of the 55-year-old female patient. The cells were grown to confluence in complete medium containing Eagle's Minimum Essential Medium (EMEM, ATCC ${ }^{\circledR}$ 30-2003 ${ }^{\mathrm{TM}}$ ), supplemented with $1 \%$ fetal bovine serum (ATCC $^{\circledR} 30-2021^{\mathrm{TM}}$ ) and $0.02 \%$ MycoZap Plus-CL (Lonza, Portsmouth, NH, USA) and incubated at $37^{\circ} \mathrm{C}$ in $5 \% \mathrm{CO}_{2}$ humidified ( $\left.\geq 90 \% \mathrm{RH}\right)$ atmosphere in tissue culture flasks. Complete medium was changed every $48 \mathrm{~h}$. When the culture became confluent, the cells were subcultivated by trypsinization using DetachKit (catalog number C-41220, PromoCell, Heidelberg, Germany, EU) and replated.

\section{solutions \\ Preparation of $B A, U A, O A$, and $U A+O A$}

BA, UA, and OA (analytical purity) were purchased from Fluka (Sigma-Aldrich, Steinheim, Germany). Stock solutions of BA, UA, OA, and UA+OA were prepared in sterilized dimethyl sulfoxide (DMSO; Sigma-Aldrich) and stored at $4^{\circ} \mathrm{C}$. For cell proliferation assay, stock solutions of BA, UA, and OA were diluted in DMSO (0.002, 0.02, 0.2, 2, 10, 20, 40, and $200 \mu \mathrm{M})$. To analyze a combined effect of UA and OA, these were dissolved in DMSO in two different ratios: 1:1 and 3.5:1.

\section{Evaluation of cell proliferation}

The effects of BA, UA, OA, and UA+OA on proliferation activity of WM-244-6 cells were determined with MTT colorimetric assay (Sigma-Aldrich), following the manufacturer's instructions. Briefly, the cells $\left(10^{4}\right.$ cells/well) were incubated in 96-well microplates for $24 \mathrm{~h}$ to form monolayers. Afterward, BA, UA, OA, and $U A+O A$ in selected concentrations were added to each well. The cells were thereafter incubated in a humidified atmosphere at $37^{\circ} \mathrm{C}$ in $5 \% \mathrm{CO}_{2}$ for $4 \mathrm{~h}$, $24 \mathrm{~h}$, or $48 \mathrm{~h}$. After each period of incubation, $10 \mu \mathrm{l}$ of MTT/100 $\mu \mathrm{l}$ of complete medium was added and plates were incubated at $37^{\circ} \mathrm{C}$ for $2 \mathrm{~h}$. Then, $200 \mu \mathrm{l}$ of DMSO (Sigma-Aldrich) was added to each well to dissolve formed formazan crystals. Cells in cell culture complete medium (not treated) were used as negative controls. The extent of MTT reduction was determined spectrophotometrically at $570 \mathrm{~nm}$ (background signal at $600 \mathrm{~nm}$ ) using Tecan plate reader (Infinite 200). All treatments were performed in pentaplicates.

In addition, cell morphology was observed with an inverted microscope (DM16000B, Leica) using 
a digital camera (DFC365 FX Leica, Buffalo Grove IL, USA).

\section{Statistical analysis}

Student's t-test was used for single statistical comparisons. Results are presented as mean \pm SD. Data were analyzed using IBM SPSS 25.0 (IBM Corp., Armonk, NY). To account for multiple comparisons bias, $p<0.001$ was considered statistically significant.

\section{Results}

As shown in Figure 1, the proliferation activity was decreased from $80 \%$ to $60 \%$ when WM-266-4 cells were treated with $0.002,0.02$, and $0.2 \mu \mathrm{M}$ BA. The only exception was $24 \mathrm{~h}$ incubation of WM-266-4 cells with $0.002 \mu \mathrm{M}$ BA when cells showed slightly increased proliferative activity when compared to control. The lowest concentration of BA that caused a significant decrease of cell proliferation activity was observed when WM-266-4 cells were treated with $2 \mu \mathrm{M}$ BA for $4 \mathrm{~h}, 24 \mathrm{~h}$, or $48 \mathrm{~h}$. Furthermore, higher concentrations of $\mathrm{BA}(>2 \mu \mathrm{M})$ significantly inhibited the proliferation activity of WM-266-4 cells at all incubation times. In the latter concentration range, the cells' proliferation activity decreased even below $20 \%$.

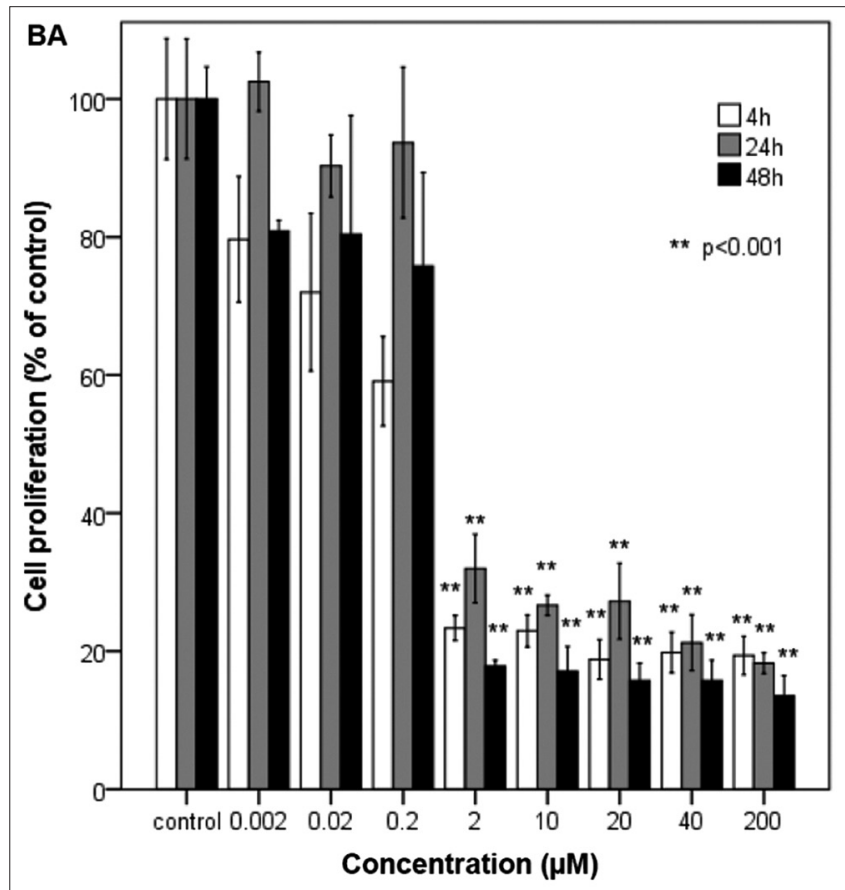

Figure 1: Inhibition of WM-266-4 cells' proliferation activity by $B A$. $D a t a$ are presented as mean $\pm S D$. Significant results are assigned as ${ }^{* *} p<0.001$ versus control. BA: Betulinic acid

When WM-266-4 cells were treated with 0.002 , $0.02,0.2 \mu \mathrm{M}$, and $2 \mu \mathrm{M} \cup \mathrm{A}$, the proliferation activity decreased up to $50 \%$. The lowest concentration of
UA that caused a statistically significant decrease of WM-266-4 cells' proliferation activity was $10 \mu \mathrm{M}$. The decrease in the cells' proliferation activity at $10 \mu \mathrm{M}$ UA was $25 \%, 10 \%$, and $5 \%$, after $4 \mathrm{~h}, 24 \mathrm{~h}$, and $48 \mathrm{~h}$, respectively. Higher concentrations of UA $(>20 \mu \mathrm{M})$ significantly inhibited the cells' proliferation activity regardless of the time of incubation $(4 \mathrm{~h}, 24 \mathrm{~h}$, or $48 \mathrm{~h})$. In the latter concentration range, the cells' proliferation activity decreased below $5 \%$. Details are evident from Figure 2.

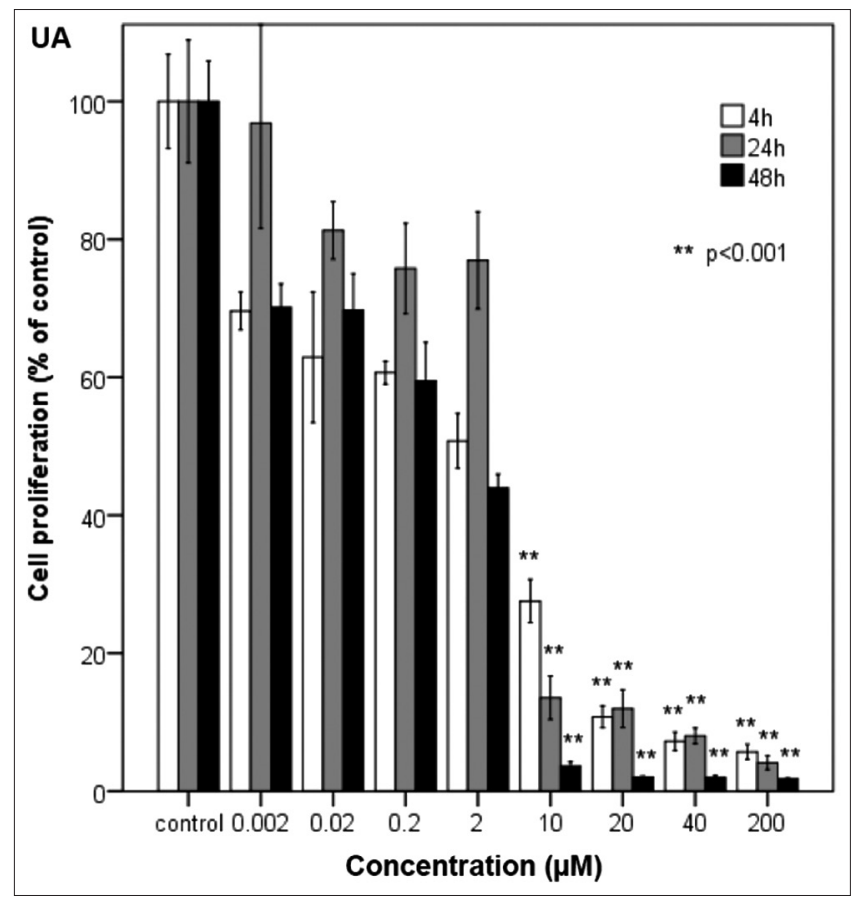

Figure 2: Inhibition of WM-266-4 cells' proliferation activity by UA. $D$ ata are presented as mean $\pm S D$. Significant results are assigned as ${ }^{* *} p<0.001$ versus control. UA: Ursolic acid

As shown in Figure 3 , the lowest $O A$ concentration that caused a significant decrease of WM-266-4 cells' proliferation activity was $20 \mu \mathrm{M}$ (10\% and $21 \%$ following $24 \mathrm{~h}$ and $48 \mathrm{~h}$ incubation, respectively). The most significant inhibition of the cells' proliferation was observed following $48 \mathrm{~h}$ incubation of WM-266-4 cells with $200 \mu \mathrm{M}$ OA.

Next, we investigated a combined effect of UA and $\mathrm{OA}$ on WM-266-4 cell proliferation activity in their two different ratios UA: OA (1:1 and 3.5:1). No significant influence on the proliferation activity was observed when concentrations of both UA and OA (1:1 and 3.5:1) were $<10 \mu \mathrm{M}$. However, when WM-266-4 cells were treated with $0.002 \mu \mathrm{M}$ UA+OA (1:1) during the period of $4 \mathrm{~h}$ a slight increase of proliferative activity when compared to control can be seen. The same effect can be seen when WM-266-4 cells were treated with UA+OA $(3.5: 1)$ for $24 \mathrm{~h}$. Furthermore, the concentration of $10 \mu \mathrm{M} \cup \mathrm{A}+\mathrm{OA}$ (both $1: 1$ and $3.5: 1$ ) caused a significant decrease of the cells' proliferation to around $20 \%, 7 \%$, and $6 \%$ following $4 \mathrm{~h}, 24 \mathrm{~h}$, and $48 \mathrm{~h}$ incubation, respectively. Higher concentrations of UA+OA $(>10 \mu \mathrm{M})$ significantly inhibited the cells' 
proliferation activity at $4 \mathrm{~h}, 24 \mathrm{~h}$, or $48 \mathrm{~h}$ of incubation. Details are evident from Figure 4.

In Figure 5, images of WM-266-4 cells with formazan granules are presented. For each tested solution, two images are shown, that is, before and after significant inhibition of cell proliferation activity.

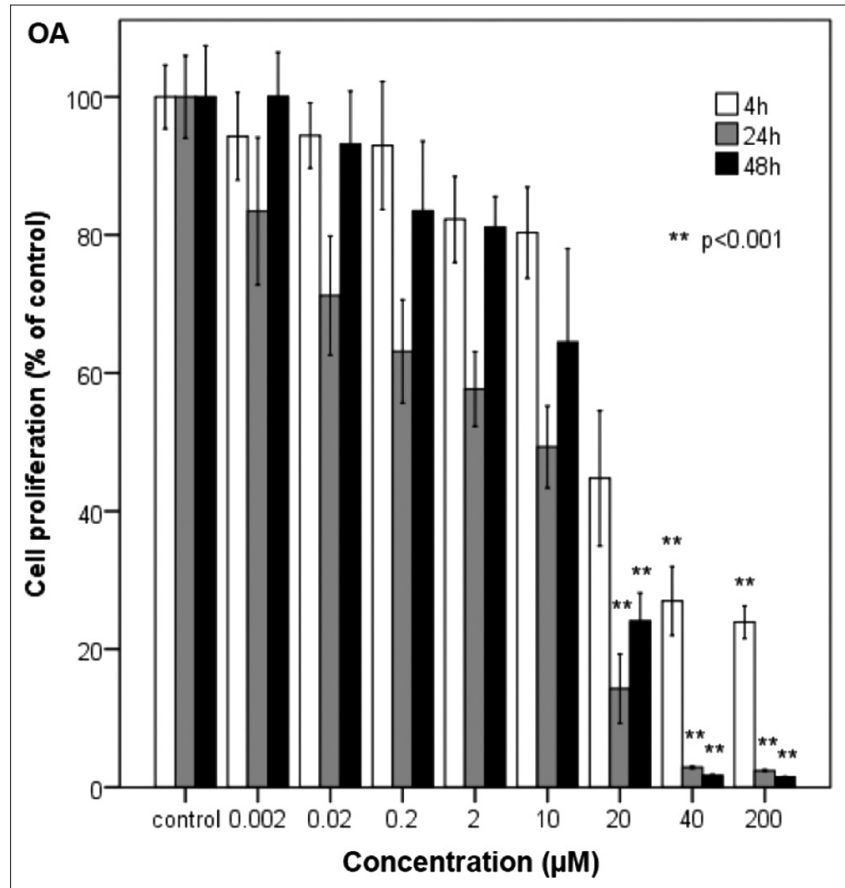

Figure 3: Inhibition of WM-266-4 cells' proliferation activity by $O A$. Data are presented as mean $\pm S D$. Significant results are assigned as ${ }^{* *} p<0.001$ versus control. OA: Oleanolic acid

\section{Discussion}

Triterpenic compounds are considered today as important constituents of the human diet regarding their anticancer properties. Using human and murine melanoma cell lines, several mechanisms have been proposed to explain their anticancer activity including cytotoxicity, inhibition of cell proliferation, as well as their effect on cell differentiation and angiogenesis processes [5], [16].

The present study focused on the effect of three triterpenic acids, that is, BA, UA, and $\mathrm{OA}$ on the proliferative activity of metastatic melanoma cells. Metastatic form of the melanoma remains difficult and presents a great clinical challenge to treat. The treatment of malignant melanoma usually includes surgery, radiotherapy, and chemotherapy, all of which show a limited selectivity for tumor cells at the same time causing adverse effects to other living cells in the body [14], [16]. For that reason, many studies have focused on using natural products to prevent and/ or treat cancer [8], [16], [17], [18], [19], [20]. Herbs and plants have been a source of prophylaxis and medicinal treatments for thousands of years, although their use was diminished when synthetic drugs were introduced. However, herbal medicine still plays an essential role in the primary health care of $80 \%$ of the world's underdeveloped and developing countries [6]. Furthermore, plants present a good source of a variety of bioactive compounds, among which, an important group is triterpenes that can be found in fruit peel,

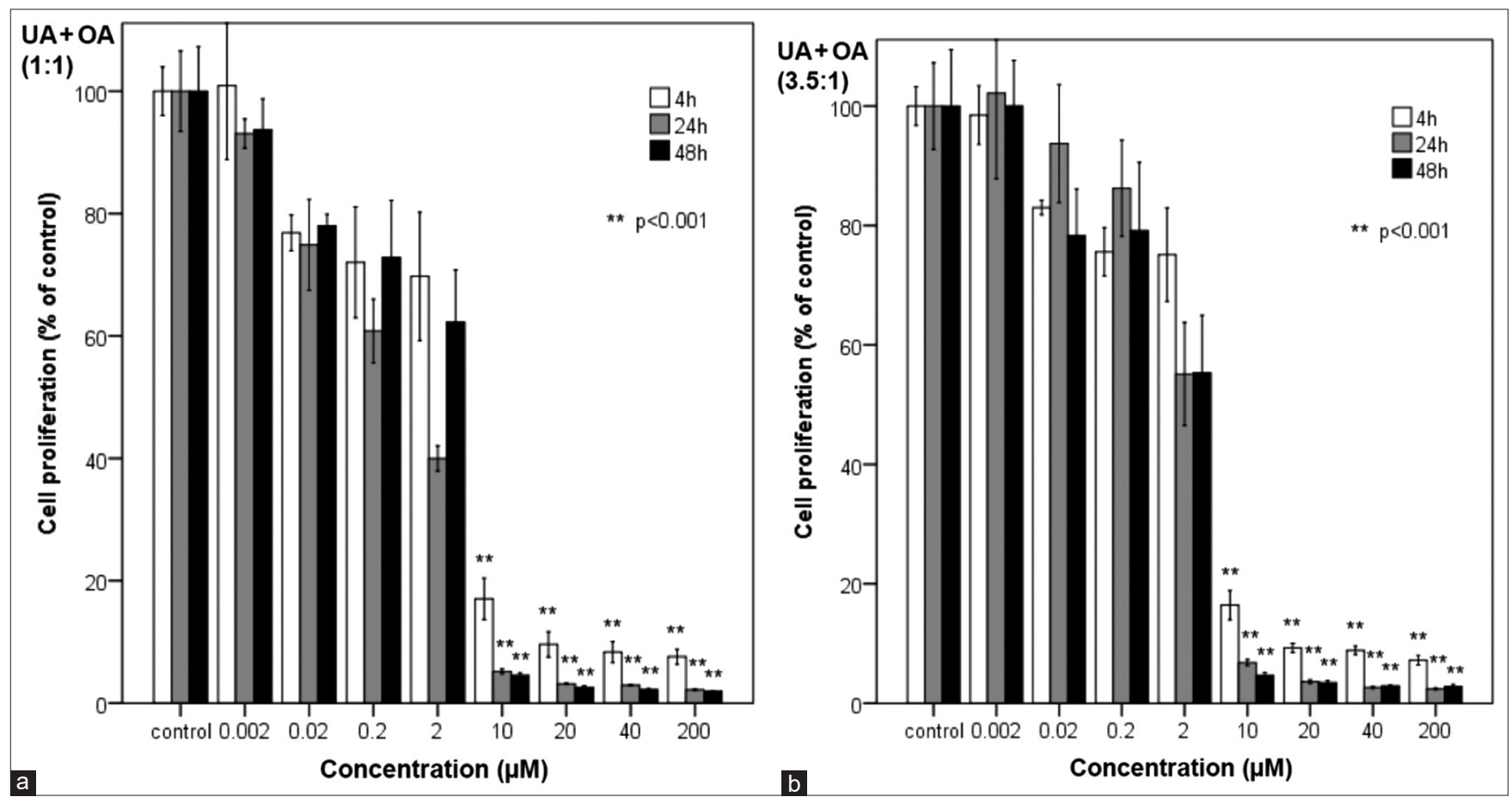

Figure 4: (a) Inhibition of the WM-266-4 cells' proliferation activity by combination of UA+OA (1:1). Data are presented as mean $\pm S D$. Significant results are assigned as ${ }^{* *} p<0.001$ versus control. (b) Inhibition of the WM-266-4 cells' proliferation activity by combination of UA+OA (3.5:1). Data are presented as mean $\pm S D$. Significant results are assigned as ${ }^{* *} p<0.001$ versus control. UA: Ursolic acid, OA: Oleanolic acid 


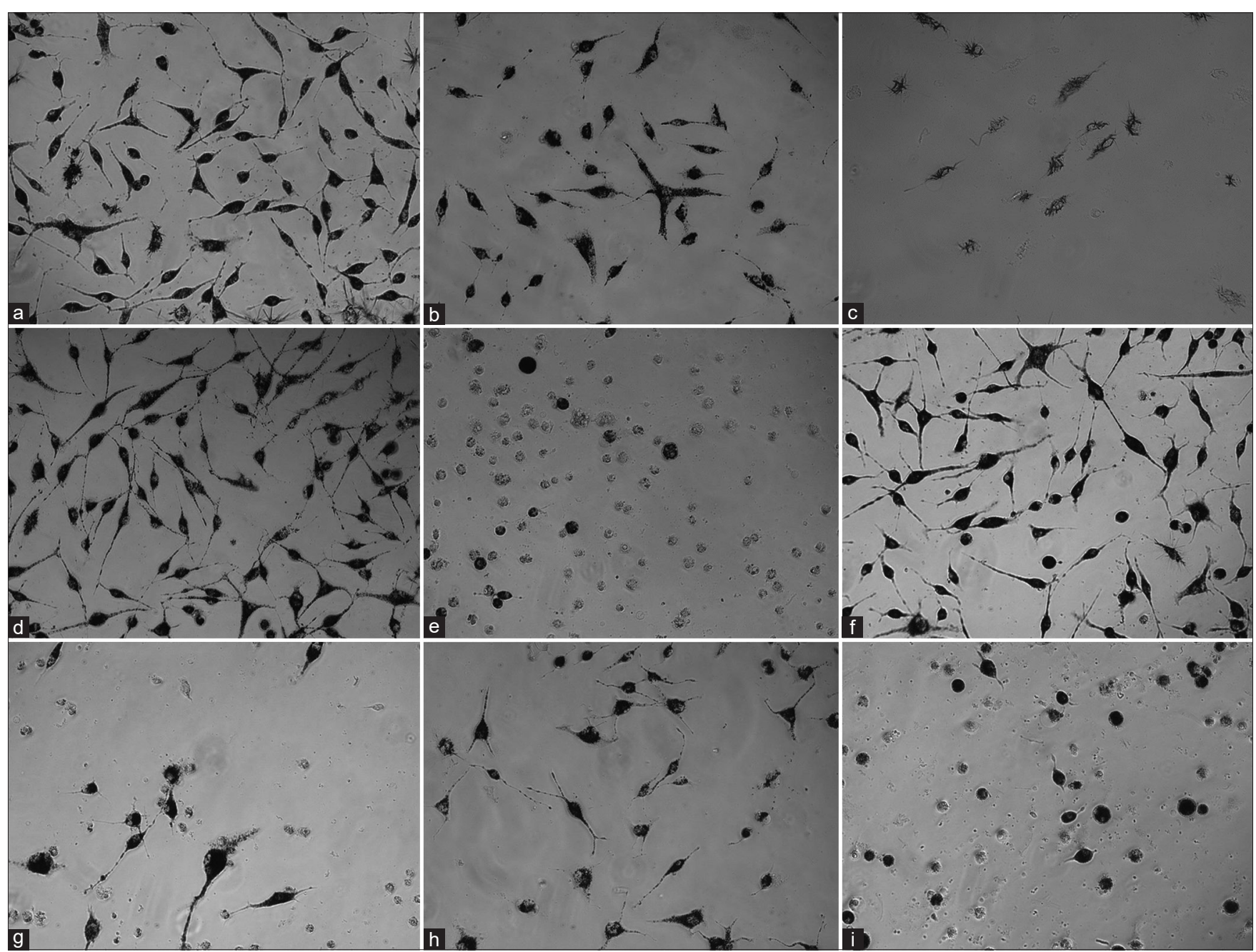

Figure 5: WM-266-4 cells with MTT formazan granule (24 h exposure time): Control (a). $0.2 \mu M$ BA (b) and $2 \mu M$ BA (c). $2 \mu M$ UA (d) and $10 \mu M \cup A(e) .10 \mu M$ OA (f), $20 \mu M$ OA (g). $2 \mu M$ OA+UA (1:1) (h) and $10 \mu M$ OA+UA. $\times 200$ (3.5:1) (i). BA: Betulinic acid, OA: Oleanolic acid, UA: Ursolic acid

leaves, and stem bark [16], [17]. Among these, BA, $\mathrm{UA}$, and $\mathrm{OA}$ have been exploited recently due to their pleiotropic biological activities [17], [18]. Particularly, their antitumor potential against various cancers has been described in several recently published articles [17], [18], [19], [20], [21], [22].

In our study, we investigated the influence of the latter compounds on the WM-266-4 metastatic melanoma cells' proliferation. Selected concentrations were similar to those used in the previous studies, although a wider range of concentrations was used in the present study $(0.002-200 \mu \mathrm{M})$. The three acids are poorly soluble in water due to their cholesterollike chemical structure and for that reason they were dissolved in DMSO.

BA exhibits potent anti-tumor activities by triggering the mitochondrial path to apoptosis [17]. It showed cytotoxic activity on different cancer cell lines, including neuroblastoma, melanoma, glioblastoma, head-and-neck cancer, ovarian and cervix carcinoma, lung carcinoma, and leukemia [17], [25], [26]. Our results demonstrated good antiproliferative activity of BA against WM-266-4 cells confirming previous observations. In our study, BA also proved to be more effective at lower concentrations than $\cup A, O A$, or $\cup A+O A$ and inhibition of proliferation was rather constant over the concentration range $(2-200 \mu \mathrm{M})$ regardless of the time of incubation.

UA is a pentacyclic triterpenoid derived from berries, fruits, leaves, and flowers of medicinal plants, such as $R$. officinalis [15]. UA has been shown to inhibit tumorigenesis, tumor promotion and suppress angiogenesis. Scientists found that UA inhibits cell proliferation and induces apoptosis through both mitochondrial death pathway and extrinsic death receptor-dependent pathway in human breast cancer cell line, MDA-MB-231 [27]. The antiproliferative activity of UA has been demonstrated in a wide variety of cancer cell lines [19], [20]. Baishya et al. (2016) demonstrated cytotoxic activity of UA using B16F10 human melanoma cell line [11]. Our results are in accordance with the results of the previous studies. In our study, proliferation assay showed that UA exhibited strong antiproliferative activity against WM-266-4 cells. In our study, UA was more efficient on WM-266-4 cell line than BA; however, BA was more potent (more effective at lower concentration than UA). 
OA was also chosen for the antiproliferative activity assay as it was already shown that it exhibited cytotoxic activity against many cancer cell lines [21], [20]. In addition, UA and OA exhibited good cytotoxic activity against the A549 cell line in the previous studies [18], [28]. The mechanism of apoptotic effect induced by OA has been studied in different types of cancer cell lines. Recent studies revealed that OA induces apoptosis through the mitochondrial pathway, with the generation of reactive oxygen species and mitochondrial fatty acid oxidation [13], [18]. In our study, proliferation activity of OA treated cells was significantly decreased at concentrations of $20 \mu \mathrm{M}$ and higher after incubation of $24 \mathrm{~h}$ and $48 \mathrm{~h}$. However, OA was less effective in inhibiting WM-266-4 cells' proliferation activity than BA and UA.

In attempt to improve antiproliferative activity of $\mathrm{OA}$ and with the aim to test if OA and UA synergistically interact in their antiproliferative activity, two mixtures of $U A+O A$ were prepared in ratios - UA: OA 1:1 and UA: OA 3.5:1. The latter ratio more reflects the ratios in which both acids can be naturally found in rosemary. Our results showed that exposure of WM-266-4 cells to concentrations of UA+OA $10 \mu \mathrm{M}$ and higher caused a significant loss of the cells' proliferation activity, more pronounced with longer incubation period. However, the combined UA+OA antiproliferative effects on WM-266-4 melanoma cell line did not differ significantly compared to the effects of UA exposure separately. Moreover, OA is less potent in inhibiting the WM-266-4 proliferation activity than UA. It could be speculated that OA effects are masked by UA effects and that the two tested substances do not interact significantly. Therefore, our results cannot confirm the results of Soica et al. who demonstrated a synergistic anti-tumor effect of UA and OA over the concentration range 40-100 $\mu \mathrm{M}$ using A375 human melanoma cell line [29].

Overall, the use of BA, UA, OA, and their both combinations resulted in a decreased proliferative activity of WM-266-4 cells. However, a concentration $0.002 \mu \mathrm{M}$ during different incubation periods resulted in slightly increased proliferative activity (i.e. $24 \mathrm{~h}$ of incubation for both BA and UA+OA (3.5:1), and the same concentration of UA+OA (1:1)) during the shorter incubation period of $4 \mathrm{~h}$. Such an increase of proliferative activity might reflect cellular protective or adaptation mechanisms as a response to an adverse change in the environment.

\section{Conclusion}

Many studies have recently described the numerous biological activities of terpenoids, with particular interest in their anti-tumor activity. Triterpenoids act at various stages of tumor development and their anti-tumor properties were demonstrated against various types of cancer cells. We report promising inhibitory effect of the three selected triterpenoid acids, BA, UA, and OA on WM-266-4 metastatic melanoma cells' proliferation activity. However, further studies are necessary to elucidate the mechanisms of the antiproliferative activity. The effectiveness of pharmacokinetic properties of pure triterpenic acids BA, UA, and OA which we used in our study could most likely be improved with the use of their more potent derivatives. A significant disadvantage in terms of bioavailability of BA, UA, and OA is their low water solubility. Further studies will be necessary to overcome this issue and to improve antitumor drug delivery with possible use of different inclusion complexes, liposomes, or nanotechnology.

\section{Acknowledgment}

The authors are thankful to Mr. Alojz Tapajner from the Faculty of Medicine, University of Maribor, for performing statistical analyses as well as for his valuable suggestions in interpreting statistical results.

\section{References}

1. Carr S, Smith C, Wernberg J. Epidemiology and risk factors of melanoma. Surg Clin N Am. 2019;100(1):1-12.

PMid:31753105

2. DeVita H, Rosenberg SA. Cancer: Principles and Practice of Oncology. $10^{\text {th }}$ ed. New York: Lippincott Williams and Wilki; 2018.

3. Tripp MK, Watson M, Balk SJ, Swetter SM, Gershenwald E. State of the science on prevention and screening to reduce melanoma incidence and mortality: The time is now. CA Cancer J Clin. 2016;66(6):460-80. https://doi.org/10.3322/caac.21352 PMid:27232110

4. Forsea AM. Melanoma epidemiology and early detection in Europe: Diversity and disparities. Dermatol Pract Concept. 2020;10(3):e2020033. https://doi.org/10.5826/dpc.1003a33 PMid:32642304

5. Padma VV. An overview of targeted cancer therapy. Biomedicine. 2015;5(4):19

PMid:26613930

6. Wink M, Schimmer O. Molecular modes of action of defensive secondary metabolites. Ann Plant Rev Online. 2018;39:418. https://doi.org/10.1002/9781119312994.apr0418

7. Abu-Darwish M, Efferth T. Medicinal plants from near east for cancer therapy. Front Pharmacol. 2018;9:56. https://doi. org/10.3389/fphar.2018.00056

PMid:29445343

8. Andrade JM, Faustino C, Garcia C, Ladeiras D, Reis CP, Rijo P. Rosmarinus officinalis L.: An update review of its phytochemistry and biological activity. Future Sci. 2018;2018:FSO283. https:// 
doi.org/10.4155/fsoa-2017-0124

PMid:29682318

9. Kashyap D, Tuli HS, Garg VK, Bhatnagar S, Sharma AK. Ursolic acid and quercetin. Promising anticancer phytochemicals with antimetastatic and antiangiogenic potential. Tumor Microenviron. 2018;1:9-15. https://doi.org/10.4103/tme.tme_3_17

10. Liu B, Ezeogu L, Zellmer L, Baofa Y, Ningzhi X, Dezhong JL. Protecting the normal in order to better kill the cancer. Cancer Med. 2015;4(9):1394-403. https://doi.org/10.1002/cam4.488 PMid:26177855

11. Baishya R, Nayak DK, Kumar D, Sinha S, Gupta A, Ganguly S, et al. Ursolic acid loaded PLGA nanoparticles: In vitro and in vivo evaluation to explore tumor targeting ability on B16F10 melanoma cell lines. Pharm Res. 2016;33:2691-703. https://doi. org/10.1007/s11095-016-1994-1 PMid:27431865

12. Momtaz S, Niaz K, Maqbool F, Abdollahi M, Rastrelli L, Nabavi SM. STAT3 targeting by polyphenols: Novel therapeutic strategy for melanoma. Biofactors. 2017;43(3):347-70. https:// doi.org/10.1002/biof.1345

PMid:27896891

13. Kim GJ, Jo HJ, Lee KJ, Choi JW, An JH. Oleanolic acid induces p53-dependent apoptosis via the ERK/JNK/AKT pathway in cancer cell lines in prostatic cancer xenografts in mice. Oncotarget. 2018;29(9):26370-86. https://doi.org/10.18632/ oncotarget.25316

PMid:29899865

14. Dinku W, Isaksson J, Rylandsholm FG, Bouř $P$, Brichtová $E$, Un Choi $\mathrm{S}$, et al. Anti-proliferative activity of a novel tricyclic triterpenoid acid from Commiphora africana resin against four human cancer cell lines. Appl Biol Chem. 2020;63:16. https:// doi.org/10.1186/s13765-020-00499-w

15. Lamponi S, Baratto MC, Miraldi E, Baini G, Biagi M. Chemical profile, antioxidant, anti-proliferative, anticoagulant and mutagenic effects of a hydroalcoholic extract of Tuscan Rosmarinus officinalis. Plants. 2021;10(1):97. https://doi. org/10.3390/plants10010097

PMid:33418860

16. Chudzik M, Korzonek-Szlacheta I, Król W. Triterpenes as potentially cytotoxic compounds. Molecules. 2015;20:1610-25. https://doi.org/10.3390/molecules20011610 PMid:25608043

17. Bildziukevich U, Özdemir Z, Wimmer Z. Recent achievements in medicinal and supramolecular chemistry of betulinic acid and its derivatives. Molecules. 2019;24(19):3546. https://doi. org/10.3390/molecules24193546

PMid:31574991

18. Oprean C, Ivan A, Bojin F, Cristea M, Soica C, Draghia L, et al. Selective in vitro anti-melanoma activity of ursolic and oleanolic acids. Toxicol Mech Methods. 2018;28(2):148-56. https://doi.org /10.1080/15376516.2017.1373881 PMid:28868958

19. Shao J, Fang $\mathrm{Y}$, Zhao R, Chen F, Yang M, Jiang J, et al. Evolution from small molecule to nano-drug delivery systems:
An emerging approach for cancer therapy of ursolic acid. Asian J Pharm Sci. 2020;15(6):685-700. https://doi.org/10.1016/j. ajps.2020.03.001

PMid:33363625

20. López-Hortas L, Pérez-Larrán $P$, Gonzáles-Muňoz MJ, Falque E, Domínguez H. Recent developments on the extraction and application of ursolic acid. Food Res Int. 2018;103:130-49. https://doi.org/10.1016/j.foodres.2017.10.028 PMid:29389599

21. Zhu YY, Huang HY, Wu YL. Anticancer and apoptotic activities of oleanolic acid are mediated through cell cycle arrest and disruption of mitochondrial membrane potential in HepG2 human hepatocellular carcinoma cells. Mol Med Rep. 2015;12(4):50128. https://doi.org/10.3892/mmr.2015.4033 PMid:26151733

22. Bai $\mathrm{X}$, Lai $\mathrm{T}$, Zhou $\mathrm{T}$, Li $\mathrm{Y}$, Li $\mathrm{X}$, Zhang $\mathrm{H}$. In vitro antioxidant activities of phenols and oleanolic acid from mango peel and their cytotoxic effect on a549 cell line. Molecules. 2018;23(6):1395. https://doi.org/10.3390/molecules23061395 PMid:29890672

23. Gidwani B, Vyas A. A comprehensive review on cyclodextrinbased carriers for delivery of chemotherapeutic cytotoxic anticancer drugs. Biomed Res Int. 2015;2015:198268. https:// doi.org/10.1155/2015/198268

PMid:26582104.

24. Sun HX, Zhang JX, Ye YP, Pan Y, Shen Y. Cytotoxic pentacyclic triterpenoids from the rhizome of Astilbe chinensis. Helv Chim Acta. 2003;86(7):2414-23. https://doi.org/10.1002/ hlca.200390194

PMid: 15013190

25. Dash SK, Chattopadhyay S, Karmakar P, Roy S. Antileukemic activity of betulinic acid from bulk to self-assembled structure. BLDE Univ J Health Sci. 2016;1:14-9. https://doi. org/10.4103/2456-1975.183269

26. Hordyjewska A, Ostapiuk A, Horecka A, Kurzepa J. Betulin and betulinic acid: triterpenoids derivatives with a powerful biological potential. Phytochem Rev. 2019;18:929-51. https:// doi.org/10.1007/s11101-019-09623-1

27. Yin R, Li T, Tian JX, Liu RH. Ursolic acid, a potential anticancer compound for breast cancer therapy. Crit Rev Food Sci Nutr. 2018;58(4):568-74. https://doi.org/10.1080/10408398.2016.120 3755

PMid:27469428

28. Gao $Y$, Yuan $Y$, Song G, Lin SQ. Inhibitory effect of ursolic acid and oleanolic acid from Eriobotrya fragrans on A549 cell viability in vivo. Genet Mol Res. 2016;15(2):239-42. https://doi. org/10.4238/gmr.15028642 PMid:27323036

29. Soica C, Oprean C, Borcan F, Danciu C, Trandafirescu C, Coricovac $D$, et al. The synergistic biologic activity of oleanolic and ursolic acids in complex with hydroxypropyl- $\gamma$-cyclodextrin. Molecules. 2014;19:4924-440. https://doi.org/10.3390/ molecules 19044924

PMid:247474649 